\title{
AN INTERNATIONAL MUNICIPAL BUREAU
}

$\mathrm{T}$

HERE exist at present in a number of countries national municipal associations. In the United States there are, for example, the National Municipal League, the League of American Municipalities, the various state leagues, associations of mayors and similar standard organizations; in Canada the Union of Canadian Municipalities, and its children the various provincial unions; in England the Board of Associated Municipalities, in Scotland the Convention of Scottish Burghs; in South Africa the South African Municipal Association; on the continent of Europe various groupings. They have no regular communication with each other; yet each is in possession of experiences and methods which might be of use to the rest for purposes of comparison and adoption, not to mention that progress, enlightenment and humanitarian kindnesss which come from a simple knowledge of the rest of the world.

I have been for some time proposing to form what might be named the International Municipal congress and Bureau, whose membership shall be composed primarily of existing municipal associations. To these might be added other classes of members, such as cities, governments and universities; also, honorary members, and associate members, such as eminent students of political science. In each country a secretary-treasurer would be appointed, preferably the secretary of one of the principal national municipal associations. His present office would be made the bureau of information of this international association. The expenses would be raised by him from the membership within his particular country. His principal duties would be to establish regular intercommunication with all the other offices of the same kind, obtain exchange of all publications, and maintain his share of an international bureau of information for the use of members and the public. One of these offices, to be chosen later, would be the central office. In the meantime a provisional centre of organization might be chosen by those first interested. The National Municipal League is in my opinion the natural centre for such organization.

Every few years a congress might be held, arranged much like other municipal gatherings. Some city would extend its hospitality and the use of its buildings, delegates would attend, discuss the programme, and elect officers. These congresses could not fail to be of a most interesting and instructive character, and the information brought back, and the other results attained, would be highly valuable. For instance, it is obvious that no municipal delegate from America could visit the City of Paris under such friendly official guidance without bringing back useful knowledge. Nor could he visit Glasgow, Birmingham, London, Berlin, or Brussels in vain. While, conversely, the New World has a great deal that would interest delegates from Europe, Australia, or South Africa. But 
if such a congress be not convenient the establishment of regular correspondence on a recognized basis would be a great instrument of advantage, and could be made productive of large benefits to civilization.

The idea so far has been favorably received. It is thought well of by good judges in America and England; and the Union of Canadian Municipalities has formally endorsed it. It is respectfully suggested that the executive of the National Municipal League take it into favorable consideration, and take such action upon it as they may deem expedient. If so, at least this continent and the British Empire could be speedily brought into line.

W. D. Lighthall, K.C. ${ }^{1}$

${ }^{1}$ Honorary Secretary of the Union of Canadian Municipalities, Montreal. 